\title{
Is corruption distasteful or just another cost of doing business?
}

\author{
Ritwik Banerjee ${ }^{1} \cdot$ Amadou Boly $^{2} \cdot$ Robert Gillanders $^{3}$ (D)
}

Received: 16 July 2020 / Accepted: 14 June 2021 / Published online: 1 July 2021

(c) The Author(s) 2021

\begin{abstract}
Using data from a lab experiment carried out in Kenya, we show that while "legitimate" costs and costs imposed by corruption both deter investment, the latter is no more of a disincentive than the former. We interpret the evidence as consistent with the conclusion that our participants viewed corruption as just another cost of doing business. We also experimented with giving participants in some treatments information about the corruption expectations of participants in previous sessions and the actual extent of corruption in previous sessions. We find some evidence that the objective information actually increased investment without changing the participants' own expectations regarding corruption. That result is compatible with the idea that revealing the level of corruption changes the descriptive norm and facilitates investment in a corrupt environment.
\end{abstract}

Keywords Compliance $\cdot$ Corruption $\cdot$ Embezzlement $\cdot$ Norms

\section{Introduction}

Understanding the factors that underlie individual economic decision-making is a question of fundamental importance for firms, governments, and society in general. Investment has been found to be influenced by a host of fundamental economic variables such as tax rates (Djankov et al., 2010), tax complexity (Lawless, 2013), exchange rates (Froot \& Stein, 1991; Udomkerdmongkol et al., 2009), market potential (Head \& Mayer, 2004), and other spatial considerations (Blonigen et al., 2007). However, noneconomic factors also matter for investment decisions. For example, both Guiso et al (2008) and Georgarakos and Pasini (2011) find that low levels of trust are negatively associated with stock market participation. Relatedly, Dearmon and Grier (2011) show at the macro level that trust is important for human and physical capital accumulation. Following the seminal study of Wei (2000), many scholars have shown that corruption and

Robert Gillanders

robert.gillanders@dcu.ie

1 Indian Institute of Management, Bangalore, India

2 African Development Bank, Abidjan, Côte d'Ivoire

3 Dublin City University Business School, Dublin, Ireland 
metrics of institutional quality attract Foreign Direct Investment (FDI) (Bénassy-Quéré et al., 2007; Daude \& Stein, 2007). Micro level evidence supports the same conclusion by finding that individuals having experience living with corrupt leaders tend to invest less (Beekman et al., 2013, 2014).

Both the experience effect and the perception effect found in FDI studies can operate by generating an expectation that a given level of investment will yield a smaller return than it would in the absence of corruption, either through an "extra tax effect" or more generally through a fear of rent-seeking behaviour. The well-documented negative association between corruption and trust (Banerjee, 2016a; Gillanders \& Neselevska, 2018; Seligson, 2002; Uslaner, 2004), combined with the above-mentioned results linking trust and investment, provides another mechanism through which corruption could disincentive economic activity.

However, another mechanism that could explain, at least in part, the observed negative relationship between corruption and economic activity is the notion that people consider corruption to be distasteful per se. If economic agents incur a significant mental cost or disutility from (passive or active) engagement in corruption, then we would expect, all else equal, that the possibility of corruption will deter people from pursuing economically profitable activities. Our main contribution is to test that hypothesis.

This paper asks if the distasteful nature of corruption reduces the extent to which people are willing to engage in transactions in which corruption is present. Our novel experimental design allows us to disentangle the effect of the simple presence of a cost from the effect of it being corrupt as opposed to honest. In our control treatment, investment is costless. Relative to that scenario, a treatment in which "public officials" could embezzle from invested funds was no more of a disincentive to investment than a treatment in which a computer levied administrative costs, although both cost treatments generated significant and sizable disincentives to investment. We therefore conclude that corruption was seen by our participants as just another cost of doing business.

The multi-faceted links outlined above between levels of investment, welfare, trust and corruption further motivate the need for an experimental approach to studying the causal effect of corruption on investment behavior. Thus, we add value to the existing literature by showing that in our experimental setup, corruption, like any cost of doing business, causes investment to be lower.

Our design also allows us to add to our understanding of how information about costly unethical behavior can change expectations, norms and behaviours. In particular, our exploration of the issue sheds light on how agents in a corrupt environment use information and the weights they assign to hard data as opposed to opinion. While a signal based on the subjective expectations of others has no statistically significant effect, we report some evidence suggesting that providing information on corruption experiences gleaned from earlier treatments actually increases investment. That information could influence investment decisions by changing investors' expectations regarding the extent of embezzlement. We do not find any evidence to support that mechanism and suggest that the information on how people actually behave changes the descriptive norm and facilitates investment even in the face of corruption.

Finally, we contribute to the experimental literature on corruption in general by lintroducing a design wherein the amounts embezzled has a direct bearing on the returns to investment. Prior designs in the experimental corruption literature largely have focused on bribery and have aimed to identify the deterrent effect of monitoring and punishment suggested in the theoretical work of Becker (1968) (e.g., Abbink et al., 2002). Our finding of 
a no distaste effect reinforces the conclusion that deterrence policies based on monitoring and punishment are needed to curb corruption.

We conducted the experiment in Kenya, as that country generally is perceived to be corrupt in a global sense but ranks only slightly below the average for sub-Saharan Africa according to Transparency International's 2019 Corruption Perceptions Index. The Kenyan venue allows us to conduct our experiment in a typical context in which corruption is salient. Moreover, Kenya is home to a renowned facility for behavioral and experimental economics.

The remainder of this paper proceeds as follows. We first present the hypotheses that motivated our experiment. We then outline our experimental design and describe the characteristics of our participants before presenting our results and discussing their limitations and implications.

\section{Motivation and hypotheses}

\subsection{The moral costs of corruption}

While many economic and institutional considerations influence investment decisions, the focus of our study is the idea that people harbor a distaste for corruption that may change their behavior over and above any other aspects of their interactions. The idea that agents incur a disutility from acting dishonestly has both theoretical and empirical support. Bernheim and Kartik (2014), for example, model politicians as being motivated in part by disutility they incur from "selling out" to special interests. Dong et al. (2009) posit that both citizens and public officials face a disutility of guilt from bribery and that that cost falls as corruption becomes more widespread. Similarly, Kessler and Leider (2012) motivate their experimental work on norms and contract violations with a model in which an individual incurs disutility when his or her behavior violates an established norm.

The explanations for preferences for honesty have been categorised as an inherent distaste for corruption (Tirole, 1996) or "predispositions" towards corporate illegality (Baucus, 1994), reputational concerns (David \& Feichtinger, 1996) and psychological barriers that often are shaped by socialization and upbringing (Nabin \& Bose, 2008). Women, at least in some contexts, have been found to be less tolerant of corruption and less willing to engage in corrupt acts (Alexander et al., 2019; Rivas, 2013). Such moral costs and preferences can tip the scales of decision making away from activities and opportunities that would otherwise be undertaken.

Existing evidence points to the possibility that triggering anti-corruption norms may deter corrupt behavior (Banerjee, 2016b; Fisman \& Miguel, 2007; Köbis et al., 2015). The literature studying peer and legitimacy effects also suggests that a moral cost must be covered in order for people to act unethically, albeit one that is lessened by exposure to such behaviors. For example, d'Adda et al. (2017) show that groups are more likely to cheat when led by someone they believe to be dishonest, while Boly et al. (2019) find a contagion effect of embezzlement and that policies originating from a corrupt source are less effective. Gatti et al. (2003) and Dong et al. (2012) find similar effects in terms of attitudes to corruption in observational data. 
Thus, a significant body of theoretical and empirical work has pointed to corruption as an act that carries meaningful disutility. Building on that literature, we ask if the threat of being a passive victim of corruption is a deterrent over and above an explicit monetary cost.

Hypothesis 1 Corruption is more of a disincentive to investment than "honest" costs of doing business.

\subsection{Corruption, information and investment}

As noted above, numerous studies have shown that corruption deters investment at the country, firm, and individual levels (Beekman et al., 2013, 2014; Fisman \& Svensson, 2007; Mauro, 1995; Wei, 2000). Significant additional costs and uncertainty are imposed on economic activities by bribery, embezzlement and other forms of corruption. Corruption serves to drive up the cost of doing business, depresses returns and it therefore is unsurprising that large negative effects of corruption on private investment have been found (Everhart et al. 2009; Zakharov, 2019). Previous studies have relied on broad aggregate measures of corruption perceptions, proxies for corruption based on estimates of missing resources, or the local incidence of bribery or corruption prosecutions. The majority of such studies also have depended on instrumental variables approaches to establish causality. Our experimental design allows us to examine the causal effect of providing information as to the likelihood of corruption in the specific context facing an investor. In our experimental setup, corruption imposes a clear cost on investors and so one might expect the following result:

Hypothesis 2a Providing investors with information that corruption is likely to reduce their returns on investment will deter investment.

Since the seminal contribution of Wei (2000), numerous studies have reaffirmed that corruption deters foreign direct investment (FDI). However, such results generally are built on the back of measures of corruption perceptions based on the views of so-called experts. Those perceptions can differ substantially from the actual experiences of firms (Razafindrakoto \& Roubaud, 2010; Treisman, 2007). Differences likewise can arise owing to perception biases in which the experts infer how corrupt a country is from their own expectations as to the outcomes generated by corruption (Fan et al., 2009). Some evidence exists that while perceptions based metrics of corruption predict a lower level of multinational activity, measures based on firm performance are not associated with FDI (Gillanders \& Parviainen, 2018). The implication is that the prominence given to empirical constructs such as the Corruption Perceptions Index may lead to sub-optimal investment decisions. As the existing evidence relies purely on observational evidence, we take the opportunity afforded by our experimental design to ask if (subjective or unfounded) perceptions have the same effect on investment decisions as more concrete signals of corruption.

Hypothesis 2b Objective information will have more of an effect on investment behavior than a signal based on the expectations or opinions of others. 


\section{Experimental design}

Our experiment was carried out in Nairobi, Kenya at the Busara Centre for Behavioural Economics. Almost all participants were university or college students. Each treatment was repeated several times over different sessions. In treatments with multiple roles, participants were assigned randomly to one of them that they kept throughout the experiment.

Each session began with the instructions being read out and questions regarding the tasks at hand were solicited. Examples of the payoff participants could receive based on their own decisions and those of others (where applicable) were then presented to them. The next step required participants to answer comprehension quizzes that were posed on their individual computer monitors. Participants were not able to proceed until they answered the questions correctly.

\subsection{Control treatment}

In our control treatment, only one role was assigned, that of an investor. All participants were paid a participation fee of 350 Kenyan Shillings (Ksh), approximately USD3.40 in mid-2017 when our first treatments were conducted. The fee was not influenced by any decisions taken in the experiment. In addition, participants had opportunities to earn further monies. Each investor had to first complete a simple task in order to earn 2000 Experimental Dollars (ED). The exchange rate was fixed at $1 \mathrm{Ksh}=9 \mathrm{ED}$ and presented clearly to participants. The investor was asked to count the number of occurrences of the letter "A" from a random sequence of letters. For example, the number of occurrences of the letter "A" in the sequence "DEWAABKACCQAJ" is four. Five sequences were provided and an investor had to count the number of occurrences of the letter " $\mathrm{A}$ " correctly in at least three sequences within five minutes. Participants had to complete that task successfully complete to proceed and were shown new sequences until they did so.

Once the preliminary task was finished, the investor faced a decision about how much of the 2000ED hee or she wanted to invest in a lottery with the following structure:

- A $10 \%$ chance that the amount invested is lost

- A $45 \%$ chance the amount invested is doubled

- A $45 \%$ chance the amount invested is tripled

The structure of the investment opportunity can be seen as a simplified and "discrete" version of the standard Investment Game experiment, first proposed by Berg et al. (1995). In a typical Investment Game, a Sender and a Receiver are paired up. Each Sender is given a certain amount of money that can be kept entirely or sent (partly or fully) to the Receiver. Any amount sent is tripled by the experimenter and given to the Receiver. The Receiver then decides whether to keep the entire amount received, or to send some back to the Sender. In our experiment, the Receiver is a computer, with a limited action set. It can retain all of the money received with a $10 \%$ chance (corresponding to the Investor losing the investment); return double the amount invested with a $45 \%$ chance (corresponding to the Investor doubling the investment); or return three times the amount sent with a $45 \%$ chance (corresponding to the Investor tripling the investment).

The investment was structured to be understood easily by participants and clearly represent an opportunity with a positive expected value. It was made clear to participants that 
the three possible outcomes were determined by a computer. The total payoff for this interaction is equal to the amount not invested plus the value of the realized return, as in an Investment Game. That information is presented to the investor clearly.

Each participant completed the procedure summarized above twice with the first and second iterations referred to as "Round 1" and "Round 2", respectively. One round was chosen randomly to serve as the basis of their earnings for the experiment. The average participant in the control treatment earned $297 \mathrm{Ksh}$ from the game. At the end of the experiment, participants were asked to complete a brief survey on socioeconomic and demographic characteristics and attitudes to corruption.

\subsection{Additional treatments}

We ran four additional treatments. In the first, Admin, investors were informed that prior to their investment being implemented the computer would deduct an administrative fee. No such cost was present in the control treatment. Specifically, in the Admin treatment, investors were told that "there are costs that must be paid in order for the investment to materialize" and that "this cost is determined at random by the computer and can be anything between 0 and 50\% of the amount invested." Once again, examples were provided and comprehension quizzes had to be answered correctly before the participant could proceed. Participants were asked to indicate their expectation of the cost given choices of 0-50\% in increments of 10. Comparing the control treatment with Admin allows us to ascertain if administrative costs that are part of the legitimate institutional rules of the game, reduce investment.

The treatment hereafter referred to as Corruption, differs from the control and Admin treatments in that we introduce a second type of participant, that of Public Official. Both types of participants were informed that they had been paired randomly with another person sitting in another room and that all decisions were anonymous. The Public Official had only one decision to make, namely how much of the amount the Investor chose to invest they wished to embezzle. The Public Official received a fixed salary of 2000ED and the amount embezzled was added to that number. As was the case with investors, one round was chosen at random to serve as the basis of payment for Public Officials. The treatment explicitly was framed as embezzlement and the labels "Investor" and "Public Official" refered to each of the roles. Examples and comprehension quizzes were administered to both types of participant. The Investor was informed that "The Public Official can embezzle (i.e., keep) some of the amount invested before implementing the investment. The amount embezzled can be anything between 0 and 50\% of the amount invested." This treatment was carried out before the Admin treatment and the distribution of corruption costs was relied on to generate the distribution of "honest" administrative costs.

Thus, we implemented the same distribution of costs with a loaded term - 'amount embezzled' in one treatment and a neutral term "administrative cost" in another. Framing has been adopted widely in the experimental economics literature but with mixed effects. While some studies find that framing has no effect on behavior (Brandts \& Schwieren, 2009; Cubitt et al., 2011; Dreber et al., 2013), others find compelling evidence for framing effects in games with social interactions (Keysar et al., 2008; Leliveld et al., 2008). That ambiguity finds its way into the literature on corruption, too, with some papers finding no effect of framing on corruption (Abbink \& Hennig-Schmidt, 2006), while others document that a frame matters (Banerjee, 2016b; Barr \& Serra, 2009). In this paper, we chose to use a loaded frame in order to make the context of corruption clear in the minds of the 
Fig. 1 Distributions of Round 1 administrative and corruption costs in $\mathrm{T} 1$ and $\mathrm{T} 2$
Distributions of Round 1 administrative and corruption costs in T1 and T2

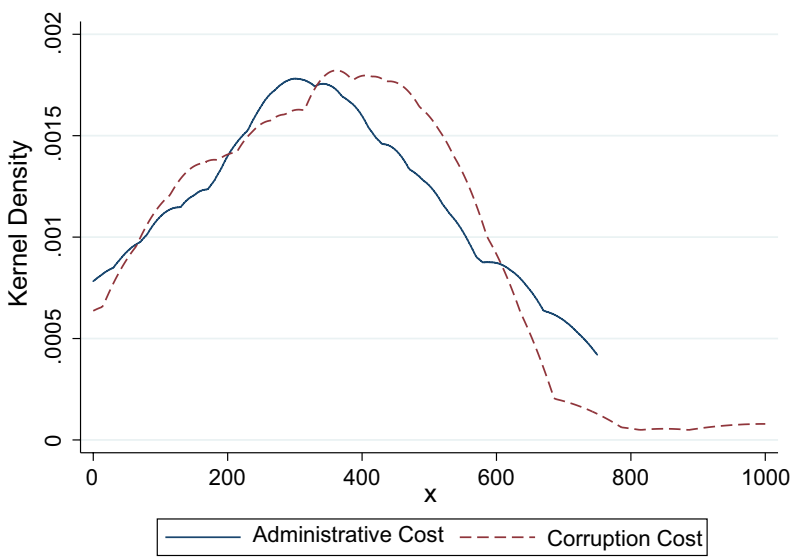

participants. What is more important in real life, individuals take decisions in such contextually loaded environments.

Figure 1 plots the distribution of imposed costs in Round 1 for those treatments. As expected and intended, the distributions look very similar. The largest realization of the cost in Admin treatment was smaller than that found in the Corruption treatment, but the Kolmogorov-Smirnov test for equality of distribution functions returns a $p$-value of 0.87 .

Investors were told how much had been embezzled at the end of each round. Everyone also was informed at the end of the first round that they would be paired, at random, with a different person for the second round. Our main focus herein is the relative importance of the treatment effects of Admin and Corruption relative to the control.

The final treatments are variations on the Corruption treatment and were carried out to examine the effects of information regarding corruption on investment behavior. Those treatments differ from the Corruption treatment by presenting investors with additional information before they make their investment decision. This additional information is derived from the Corruption treatment.

In the Perceptions treatment, investors are presented with the following information: "Half of the investors in an earlier session believed before they made any investment decision that the public officials that they were paired with would embezzle $40 \%$ or more of the funds entrusted to them." In the Objective treatment, participants were told that: "Half of the investors in an earlier session were paired with public officials that actually embezzled $40 \%$ or more of the funds entrusted to them." Those treatments therefore differ only in terms of whether the information provided is based on the expectations or experiences of previous participants taking the role of investor.

In both cases, it was stated explicitly that the earlier session had taken place in the Busara Centre. The fact that investor expectations in Corruption were in line with what they ultimately experienced in terms of embezzlement supports the notion that our investors possessed local knowledge as to how people in the role of public official would behave. That setup also is in line with Olken (2009), who examined the accuracy of Indonesian villagers' corruption perceptions relative to a more objective measure of 'missing expenditures' in a road-building project in their village, and found that villagers' reported that perceptions indeed do contain real information. Investors in the Corruption treatment were 
Table 1 Overview of treatments

\begin{tabular}{llllll}
\hline Treatment number & T0 & T1 & T2 & T3 & T4 \\
\hline $\begin{array}{l}\text { Treatment name } \\
\begin{array}{l}\text { Invested amount can be } \\
\text { reduced by }\end{array}\end{array}$ & Control & Admin & Corruption & Perceptions & Objective \\
\begin{tabular}{l} 
Corruption signal \\
\hline
\end{tabular} & & Costs & Corruption & Corruption & Corruption \\
\end{tabular}

incentivised to provide an accurate assessment of their own perceptions as they received an extra ED100 if their expectations matched the outcome.

Table 1 provides an overview of each treatment and the online appendix provides screenshots of the instructions and experimental implementations as presented to the participants.

To summarize, the general timeline for our treatments is as follows:

1. Participants are assigned randomly to the role of Investor or Public Official

2. Instructions and examples were provided and comprehension tested

3. Investors carried out the real effort task

4. In the Perceptions and Objective treatments, investors were provided with a signal of corruption

5. Investors made their investment decision and, where applicable, public officials made their corruption decision

6. Payoffs are calculated and new pairs are formed for the second round, which sees them repeat steps 3-5.

7. One round was selected randomly as the basis for payment

The treatments were carried out in the following order. The control treatment was carried out first, followed by the Corruption treatment. Admin was then conducted using the distribution of costs from the Corruption treatment. Finally, Objective and Perceptions were implemented using the necessary information from Corruption. Because of constraints on lab capacity, four sessions were run for each treatment, bar the Objective treatment had three. Thus, our data are derived from 19 experimental sessions.

\subsection{Subject pool}

In total, 337 participants took the role of investor in our experiment with 100 in the control, 99 in Admin, 51 in Corruption, 42 in Perceptions, and 45 in Objective. ${ }^{1}$ In the latter three treatments, in each round each investor was paired randomly with another participant serving in the role of Public Official; we thus have smaller samples of investors in those treatments (and equal numbers of public officials). Role assignment was random

\footnotetext{
1 The four sessions of the Control treatment had 23, 28, 24 and 25 participants in the role of investor. The four sessions of the Admin treatment had 30, 20, 30 and 19 participants in the role of investor. The four sessions of the Corruption treatment had 8,20,10 and 13 participants in the role of investor. The four sessions of the Perceptions treatment had 3, 14, 14 and 11 participants in the role of investor. The three sessions of the Objective treatment always had 15 participants in the role of investor.
} 
Table 2 Summary statistics

\begin{tabular}{|c|c|c|c|c|c|c|}
\hline & $\begin{array}{l}\text { Control } \\
\text { Mean (SD) }\end{array}$ & $\begin{array}{l}\text { Admin } \\
\text { Mean (SD) }\end{array}$ & $\begin{array}{l}\text { Corruption } \\
\text { Mean (SD) }\end{array}$ & $\begin{array}{l}\text { Perceptions } \\
\text { Mean (SD) }\end{array}$ & $\begin{array}{l}\text { Objective } \\
\text { Mean (SD) }\end{array}$ & $\begin{array}{l}\text { Kruskal- } \\
\text { Wallis } \\
p \text {-value }\end{array}$ \\
\hline $\begin{array}{l}\text { Amount invested in } \\
\text { Round } 1 \text { (ED) }\end{array}$ & $\begin{array}{l}963.60 \\
(453.77)\end{array}$ & $\begin{array}{l}898.13 \\
(433.71)\end{array}$ & $\begin{array}{l}899.02 \\
(367.76)\end{array}$ & $\begin{array}{l}1025.24 \\
(406.53)\end{array}$ & $\begin{array}{l}1093.33 \\
(385.33)\end{array}$ & 0.020 \\
\hline $\begin{array}{l}\text { Amount invested in } \\
\text { Round } 2 \text { (ED) }\end{array}$ & $\begin{array}{l}1000.6 \\
(528.20)\end{array}$ & $\begin{array}{l}913.63 \\
(421.60)\end{array}$ & $\begin{array}{l}900.00 \\
(517.40)\end{array}$ & $\begin{array}{l}964.31 \\
(465.37)\end{array}$ & $\begin{array}{l}903.44 \\
(484.43)\end{array}$ & 0.737 \\
\hline Age & $\begin{array}{l}23.08 \\
(1.85)\end{array}$ & $\begin{array}{l}22.42 \\
(1.88)\end{array}$ & $\begin{array}{l}22.25 \\
(1.81)\end{array}$ & $\begin{array}{l}21.93 \\
(1.73)\end{array}$ & $\begin{array}{l}21.00 \\
(1.33)\end{array}$ & 0.000 \\
\hline Gender $($ Female $=1)$ & $\begin{array}{l}0.43 \\
(0.50)\end{array}$ & $\begin{array}{l}0.26 \\
(0.44)\end{array}$ & $\begin{array}{l}0.31 \\
(0.47)\end{array}$ & $\begin{array}{l}0.29 \\
(0.46)\end{array}$ & $\begin{array}{l}0.16 \\
(0.37)\end{array}$ & 0.012 \\
\hline $\begin{array}{l}\text { Education (University } \\
\text { student }=1, \text { high } \\
\text { school or college } \\
\text { student }=0 \text { ) }\end{array}$ & $\begin{array}{l}0.98 \\
(0.14)\end{array}$ & $\begin{array}{l}0.91 \\
(0.29)\end{array}$ & $\begin{array}{l}0.94 \\
(0.24)\end{array}$ & $\begin{array}{l}0.83 \\
(0.38)\end{array}$ & $\begin{array}{l}0.73 \\
(0.45)\end{array}$ & 0.087 \\
\hline $\begin{array}{l}\text { Gross Monthly } \\
\text { Income (Ksh) }\end{array}$ & $\begin{array}{l}30,618.15 \\
(62,394.67)\end{array}$ & $\begin{array}{l}22,524.78 \\
(25,719.73)\end{array}$ & $\begin{array}{l}39,113.47 \\
(99,302.69)\end{array}$ & $\begin{array}{l}90,536.33 \\
(340,978.50)\end{array}$ & $\begin{array}{l}81,185.67 \\
(445,373.90)\end{array}$ & 0.013 \\
\hline $\begin{array}{l}\text { Interpersonal trust } \\
(\text { Trust }=1)\end{array}$ & $\begin{array}{l}0.06 \\
(0.24)\end{array}$ & $\begin{array}{l}0.06 \\
(0.24)\end{array}$ & $\begin{array}{l}0.10 \\
(0.30)\end{array}$ & $\begin{array}{l}0.00 \\
(0.00)\end{array}$ & $\begin{array}{l}0.04 \\
(0.21)\end{array}$ & 0.362 \\
\hline $\begin{array}{l}\text { Number of observa- } \\
\text { tions }\end{array}$ & 100 & 99 & 51 & 42 & 45 & \\
\hline
\end{tabular}

and participants kept the same role throughout the experiment. Table 2 presents summary statistics for our investors across each of our five treatments. Our participants were between 21 and 23 years old, on average, and statistically significant differences emerged between treatments. The participants also differed in gender composition, education, and income. Therefore, it is vital that we control for those factors in our regressions. Our exit survey also reveals that interpersonal trust is very low within our sample. Our participants overwhelmingly are university students and therefore unrepresentative of the Kenyan population as a whole. Given the processes that we are interested in experimentally approximating, though, the group is an appropriate subject pool.

\section{Results}

\subsection{Differences across Treatments}

Figure 2 presents the average outcome for the amount invested and the share of investors who invested anything for each of our five treatments. In all rounds and treatments, the likelihood of investing at least 1ED was extremely high. Indeed, in several treatments, all investors invested. We therefore focus on the extent of investment because the amount invested displays more obvious variation. That outcome varies more across treatments, although the average falls far short in all instances of the maximum amount possible (2000ED). Given the imbalances in age, gender and income across our treatments 


\section{Investment decisions by treatment}
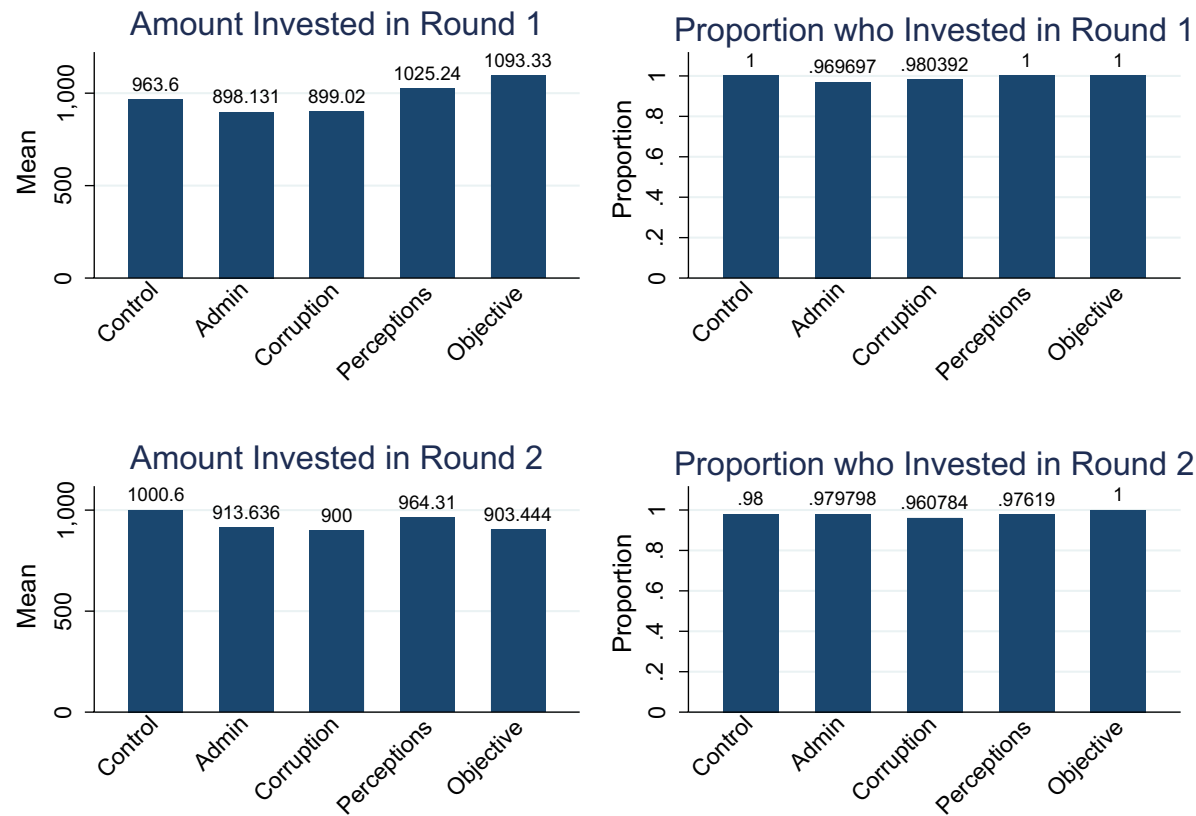

Fig. 2 Investment decisions by treatment

we proceed directly to a regression analysis that allows us to control for such potentially confounding variation.

\subsection{A distaste for corruption?}

To examine the first hypothesis, we rely on the data from the control, Admin and Corruption treatments and estimate the following model with ordinary least squares:

$$
\text { amount }_{i}=\alpha_{0}+\beta_{1} \text { Admin }_{i}+\beta_{2} \text { Corruption }_{i}+\beta_{3} \text { Controls }_{i}+\varepsilon_{i}
$$

We are interested in the coefficients of our treatment variables, $\beta_{1}$ and $\beta_{2}$, which reveal the effects of the Admin and Corruption treatment relative to the control. Intuitively, the treatment effects should be negative, indicating that either type of cost reduces the amount invested. Their relative magnitude allows us to investigate Hypothesis 1 . If it is indeed the case that a distaste for corruption is common, then $\beta_{2}$ should be significantly larger than $\beta_{1}$.

The vector of independent variables allows us to control for the cross treatment differences in average age, income, education and gender composition that we observed in Table 2. As several sessions were carried out for each of our treatments, we cluster the standard errors at the session level (11-12 clusters). To correct for the small number of clusters, we report Wild Bootstrap p-values for our main results (Roodman et al., 2019).

The first column of Table 3 shows that the Admin and Corruption treatments reduced the amount invested relative to the Control treatment. The treatment effects tell us that the 
Table 3 A distaste for corruption?

\begin{tabular}{|c|c|c|c|}
\hline & (1) & (2) & (3) \\
\hline & Round 1 & Round 2 & Round 2 \\
\hline & Amount & Amount & Amount \\
\hline Control & REF & REF & \\
\hline \multirow[t]{2}{*}{ Admin } & $-145.88 * *$ & -147.88 & REF \\
\hline & $(56.12)$ & (93.68) & \\
\hline \multirow[t]{2}{*}{ Corruption } & $-122.56^{* *}$ & -129.86 & 1.56 \\
\hline & $(43.38)$ & $(85.56)$ & $(61.60)$ \\
\hline \multirow[t]{2}{*}{ Age } & -17.02 & 13.42 & $29.49^{*}$ \\
\hline & $(14.20)$ & $(16.55)$ & $(15.20)$ \\
\hline \multirow[t]{2}{*}{ Gender $($ Female $=1)$} & $-326.13^{* * *}$ & $-255.54 * * *$ & -61.04 \\
\hline & $(51.28)$ & $(67.51)$ & $(79.41)$ \\
\hline \multirow{2}{*}{$\begin{array}{l}\text { Education }(\text { University student }=1 \text {, high school or } \\
\text { college student }=0)\end{array}$} & $-203.16^{*}$ & $-372.47^{* * *}$ & $-362.27 * * *$ \\
\hline & $(103.23)$ & (71.98) & (91.18) \\
\hline \multirow[t]{2}{*}{ Ln(gross income) } & 3.22 & 6.59 & -9.58 \\
\hline & $(13.61)$ & $(22.82)$ & $(26.08)$ \\
\hline \multirow[t]{2}{*}{ Round 1 Cost } & & & $0.78 * * *$ \\
\hline & & & $(0.20)$ \\
\hline \multirow[t]{2}{*}{ Constant } & $1991.91 * * *$ & $1359.86^{* *}$ & 487.72 \\
\hline & $(422.58)$ & $(498.19)$ & $(429.36)$ \\
\hline Observations & 250 & 250 & 150 \\
\hline $\mathrm{R}^{2}$ & 0.14 & 0.10 & 0.19 \\
\hline Wild bootstrap p-value for $A d \min =0$ & 0.048 & 0.213 & \\
\hline Wild bootstrap p-value for Corruption $=0$ & 0.075 & 0.209 & 0.98 \\
\hline Wild bootstrap p-value for $A d \min =$ Corruption & 0.727 & 0.861 & \\
\hline
\end{tabular}

Standard errors clustered at the session level are presented in parentheses; $* * *, * *$ and $*$ denote statistical significance at the 1,5 and $10 \%$ levels, respectively

amount invested is 145ED less in the Admin treatment and 122ED less in the Corruption treatment. Either type of cost significantly (both in the statistical sense of the term and in terms of magnitude) reduces the amount invested. As we cannot reject the null that these coefficients are equal ( $p$-value $=0.727$ ), we conclude that legitimate costs are no more or less of a deterrent to investment than those related to embezzlement. That conclusion holds despite the fact that investors in the Corruption treatment tended to expect higher costs than those in the Admin treatment, as shown in Fig. 3 (Epps-Singleton two-sample empirical characteristic function test $p$-value $=0.013$ ). Our findings are in line with our subjects viewing corruption as just another cost of doing business and also with the findings of Boas et al. (2019) that while anti-corruption norms can shape hypothetical behaviors, they may not be salient in actual decisions (voting in their context).

It is plausible that experience could change expectations and indeed Fig. 3 suggests that to be the case. A noticeable change in expectations is evident regarding the burden of administrative costs and corruption, with both becoming spread more evenly across the middle of the distribution. Moreover, we cannot reject the null that the distributions are equal in Round 2 (Epps-Singleton two-sample empirical characteristic function test $p$-value $=0.12$ ). Given that 


\section{Distributions of cost expectations in Admin and Corruption}
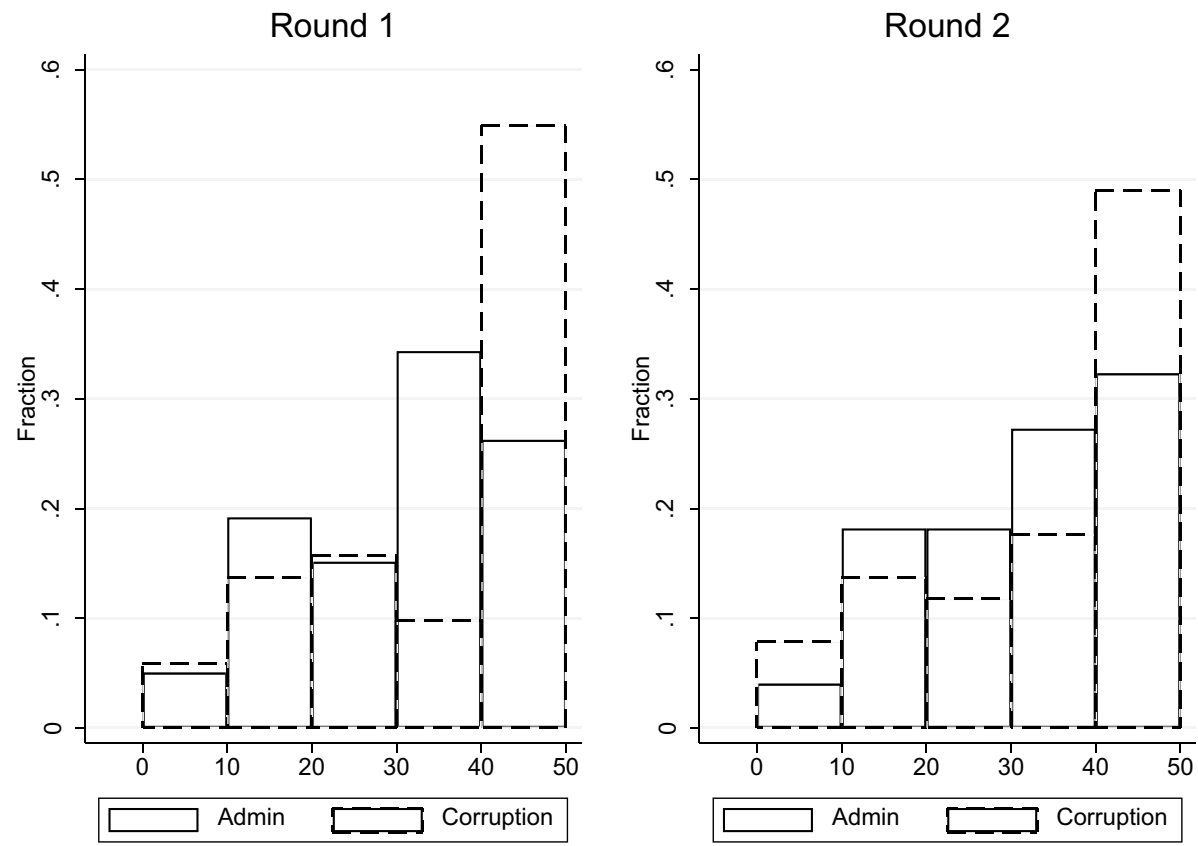

Fig. 3 Distributions of cost expectations in Admin and Corruption

adjustment in expectations, it is perhaps not surprising that neither treatment had an effect in Round 2, as can be seen in Column 2 of Table 3. The coefficients on Admin and Corruption in Column 2 are comparable to those in Column 1, but are not statistically significant. Once again, we cannot reject the null that the treatments have the same effect, a result that is consistent with the idea that experience reduces the importance of either type of uncertain cost. Column 3 of Table 3 further demonstrates that decisions in Round 2 were influenced by experiences in Round 1. Taking the Admin treatment as the baseline (as no costs were incurred in the control), we find that the cost experienced in the first round is a significant predictor of Round 2 behavior. Interestingly, the higher was the cost experienced in Round 1, the larger was the investment in Round 2. Future work could explore the process by which behaviors in investment domains adapt to experience.

\subsection{Does information change behaviour?}

Hypotheses $2 \mathrm{a}$ and $2 \mathrm{~b}$ ask if giving investors signals that corruption is prevalent reduces investment and, moreover, if objective information has more of an effect than a signal based on opinions. To answer those questions, we used the data from the Corruption, Perceptions, and Objective treatments to estimate the following regression with OLS:

$$
\text { amount }_{i}=\mu_{0}+\theta_{1} \text { Perceptions }_{i}+\theta_{2} \text { Objective }_{i}+\theta_{3} \text { Control }_{i}+\varphi_{i}
$$


Table 4 Does information change behavior?

\begin{tabular}{|c|c|c|c|c|}
\hline & \multirow{3}{*}{$\begin{array}{l}\text { (1) } \\
\text { Round } 1 \\
\text { Amount }\end{array}$} & \multirow{3}{*}{$\begin{array}{l}\text { (2) } \\
\text { Round } 2 \\
\text { Amount }\end{array}$} & \multirow{3}{*}{$\begin{array}{l}\text { (3) } \\
\text { Round } 1 \\
\text { Expectation }\end{array}$} & \multirow{3}{*}{$\begin{array}{l}\text { (4) } \\
\text { Round } 2 \\
\text { Expectation }\end{array}$} \\
\hline & & & & \\
\hline & & & & \\
\hline Corruption & REF & REF & REF & REF \\
\hline \multirow[t]{2}{*}{ Perceptions } & 115.86 & 52.92 & 0.11 & 0.12 \\
\hline & $(69.87)$ & $(84.66)$ & $(0.27)$ & $(0.20)$ \\
\hline \multirow[t]{2}{*}{ Objective } & $163.58^{*}$ & -15.35 & -0.04 & 0.17 \\
\hline & $(86.59)$ & $(116.04)$ & $(0.22)$ & $(0.14)$ \\
\hline \multirow[t]{2}{*}{ Age } & -10.54 & 3.89 & -0.04 & 0.01 \\
\hline & $(17.48)$ & $(20.91)$ & $(0.04)$ & $(0.05)$ \\
\hline \multirow[t]{2}{*}{ Gender $($ Female $=1)$} & -35.11 & 9.64 & 0.03 & 0.08 \\
\hline & $(48.76)$ & $(66.16)$ & $(0.23)$ & $(0.28)$ \\
\hline \multirow{2}{*}{$\begin{array}{l}\text { Education (university student }=1 \text {, high school } \\
\text { or college student }=0 \text { ) }\end{array}$} & -66.34 & -126.05 & -0.05 & 0.19 \\
\hline & $(125.22)$ & $(92.63)$ & $(0.26)$ & $(0.14)$ \\
\hline \multirow[t]{2}{*}{ Ln(gross income) } & 10.84 & 5.88 & 0.02 & 0.01 \\
\hline & $(14.48)$ & $(21.47)$ & $(0.03)$ & $(0.04)$ \\
\hline \multirow[t]{2}{*}{ Constant } & $1147.28 * *$ & $867.90 *$ & & \\
\hline & $(500.55)$ & $(461.66)$ & & \\
\hline Observations & 138 & 138 & 138 & 138 \\
\hline $\mathrm{R}^{2} /$ pseudo $\mathrm{R}^{2}$ & 0.05 & 0.01 & 0.00 & 0.00 \\
\hline Wild bootstrap $p$-value for Perceptions $=0$ & 0.154 & 0.566 & 0.677 & 0.547 \\
\hline Wild bootstrap p-value for Objective $=0$ & 0.107 & 0.912 & 0.884 & 0.221 \\
\hline Wild bootstrap $p$-value for Perceptions $=$ Objective & 0.523 & 0.594 & 0.629 & 0.854 \\
\hline
\end{tabular}

Standard errors clustered at the session level are presented in parentheses; ***, * and * denote statistical significance at the 1,5 and $10 \%$ levels, respectively

Finding both $\theta_{1}$ and $\theta_{2}$ to be negative and statistically significant would offer support for Hypothesis $2 \mathrm{a}$. It would tell us that signalling that public officials may embezzle significant funds reduces the extent of investment. The logic underlying Hypothesis $2 \mathrm{~b}$ would lead one to expect that $\theta_{1}<\theta_{2}$.

Columns 1 and 2 of Table 4 present the results of estimating Eq. 2 from the first and second rounds, respectively. We find only weak evidence that either type of signal changes behavior. Only in Round 1 do we find an effect that approaches the traditional threshold for statistical significance and that estimate runs contrary to Hypothesis 2a. Relative to the Corruption treatment, in the first round the Perceptions treatment increases investment by 116ED and the Objective treatment increases investment by 164ED. The coefficient on Objective in the first round is significant at the $10 \%$ level using the unadjusted clustered standard errors and just beyond that threshold using the Wild Bootstrap adjustment. The coefficient is positive, suggesting that that type of information increased investment. Once again, we do not find any effect in the second round, suggesting that the cost experienced in the first round weighs more heavily than "external" information in investment decision making. The treatment effect for Perceptions is not significant in either round.

While only the Objective treatment effect approaches the traditional threshold of (weak) statistical significance, we cannot reject the null hypothesis that the effect of Objective 
equals that of Perceptions. Therefore, in terms of Hypothesis $2 b$, we find only slight evidence that the objective experience based information is more compelling to investors than the perceptions based signal.

Columns 3 and 4 investigate a mechanism through which the information could influence investment behavior. Information about how corrupt incumbents are likely to be has been found to change voter expectations and behaviors in some experiments (e.g., Chong et al., 2015). Expectations about what we believe others will do (empirical expectations) likewise can, in some contexts at least, win out over normative expectations as drivers of our own behavior (Bicchieri \& Xiao, 2009). In our context, if signals actually reduce the amount that investors expect to lose, then providing such information could see investment rise in line with the estimated treatment effects in Table 4.

To investigate that question, expectations were solicited by asking, "How much, in terms of percent, do you think will be embezzled by the Public Official?" For the treatments featuring signals, the question was asked after the information was provided. As investors could answer $0,10,20,30,40$, or $50 \%$, we estimate ordered probit models. As can be seen from Columns 3 and 4, investor expectations were not changed by the information provided in either round of the experiment.

Our interpretation of those results is that the signal containing objective information creates a descriptive norm that corruption is acceptable and that signal, in turn, facilitates investment. In other words, seeing how people actually behave can, even if that behavior contravenes a prescriptive norm, enables people to participate in an act in which people are acting corruptly. ${ }^{2}$ The insignificance of the Perceptions treatment effect suggests that providing information about how people are perceived to behave is not sufficient to trigger a norm change.

\section{Limitations and generalizability of findings}

The presence of another person in the Corruption treatment may introduce considerations not present in Admin. Concern for the welfare of the other participant could strengthen willingness to invest in a situation in which a public official can obtain some of the investor's funds corruptly. Future work could explore that idea further by allocating the "honest" cost of the Admin treatment to an otherwise passive participant or to a charity. A deeper understanding of the motivations and mechanisms may suggest new avenues for anti-corruption policy.

One should always be aware of the external validity issue when considering a given experimental study. Simply put, what holds in one context, or point in time, need not hold everywhere and always. In the specific domain of corruption studies, some clusters of results and individual studies offer reassurance in that regard.

Firstly, the key results of the seminal experimental corruption studies have solid replication records. Abbink et al. (2002) found that in their sample of German students, even a small chance of being caught and punished had a significant deterrent effect on both bribe taking and offering. Azfar and Nelson (2007) report a similar result in a very different experimental design and a subject pool of American students. Evidence from a field experiment in Indonesia also points to the same deterrent effect (Olken, 2007). A second

${ }^{2}$ We are indebted to an anonymous referee for this insight. 
finding that speaks to the general applicability of at least some corruption experiments can be found in Armantier and Boly (2013). In that paper, the same experimental design was deployed in laboratory settings in Burkina Faso and Canada and compared with a similar field experiment in Burkina Faso. Armantier and Boly find that the treatment effects are indistinguishable across the three iterations of the experiment. Therefore, some precedent can be found for corruption experiments teaching us something meaningful about "the real world". The supposed artificiality of the laboratory context in which key aspects of the phenomenon of interest are not present (Schram, 2005) does not seem to doom corruption experiments to irrelevance.

It also is important to note the need for experiments when studying corruption. As discussed in Armantier and Boly (2012), the challenges of studying corruption quantitatively make the lab experimental approach a particularly attractive method. Credible data on corruption is hard to gather from observational sources, particularly when it relates to collusive corruption or the extractive party in a harassment corruption transaction. The lab setting likewise can provide a cost-effective method for testing new anti-corruption approaches (Abbink, 2006; Dusek et al., 2005) without falling victim to some of ethical challenges that can arise in a field experiment on corruption, which could be considered akin to exposing live patients to a carcinogen (Azfar \& Nelson, 2007). Of most relevance to the present study, the endogeneity of institutions and norms makes it very challenging to examine the roles they play in determining individual behavior. Finally, as noted by both Camerer (2015) and Kessler and Vesterlund (2015), an important distinction can be made between quantitative external validity and qualitative external validity, with the latter being of chief concern in an experimental exercise aimed at investigating comparative statics.

Nevertheless, while the foregoing arguments may reduce concerns regarding the external validity of our results, they obviously cannot eliminate them altogether. Our data were collected from participants who live in Kenya, a country ranked 137 th out of 180 on Transparency International's 2019 corruption perceptions index (where 1st place denotes the country with the "cleanest" reputation). The post-experiment survey also speaks to Kenya being a country with a severe corruption problem. When asked about how many of their government officials were engaged in corruption, $17 \%$ of participants replied "all of them", $76 \%$ "some of them", and 7\% "a few of them". Plausibly, such perceptions could alter one's attitudes towards and tolerance of corruption; future work thus should explore whether the absence of a distaste for corruption is evident in countries wherein the control of corruption is stronger. The ability of subjective or objective information on the prevalence of corruption to change descriptive norms in less corrupt contexts also warrants attention. With respect to the limitations placed on the current results, it should be noted that according to Transparency International the vast majority of people (approximately six billion) live in countries that they would categorize as corrupt (Transparency International 2018). Our findings therefore are plausibly applicable to a large number of countries and contexts in which firms may wish to do business.

\section{Conclusion}

Corruption imposes substantial costs on economies and societies, most notably by depressing growth and investment (Johnson et al., 2011; Mauro, 1995), fostering inequality and poverty (Apergis et al, 2010; Gupta et al., 2002), undermining trust in politicians and institutions (Morris \& Klesner, 2010; Seligson, 2002) and fuelling the rise of 
populism (Foresta, 2020). Fisman and Svensson (2007) show that in terms of a Ugandan firm's growth rate, bribery has a larger negative effect than taxation. An appreciation of the forces that drive the willingness of people to participate in transactions in which corruption is a prominent feature therefore is of substantial importance. All too often, we learn that firms from both developing and developed countries are active participants in corruption. In many instances, such failures of "compliance" arise when agents of multinationals are operating in countries where corruption is endemic.

While the fact that our experiment was carried out in a particular context has clear implications for the external validity of our results, we believe that, taken as a whole, they point to a clear conclusion. In a context in which corruption is widespread, such as Kenya, people view corruption as no more of a deterrent to investment than "legitimate" costs of doing business. Corruption carries no additional psychic cost in such contexts and no disengagement with economic opportunities is evident owing to a distaste for behavior that is viewed as immoral. Our results also suggest that credible information as to the extent of corruption actually can increase investment by changing the descriptive norm.

The willingness of actors in corrupt environments to participate in interactions in which corruption is likely is cause for concern in terms of the ability for even well-intentioned firms to refrain from engaging in or combating corruption. Not only do firms arguably have an ethical obligation to refrain from participating in corrupt activities (Rose-Ackerman, 2002), but laws such as the United States' Foreign Corrupt Practices Act expose firms to significant penalties if their agents do. If a firm's local agents and "fixers" in a corrupt country do not harbor a distaste for corruption they are more likely to engage in corrupt actions and expose the firm to fines and sanctions. Principal-agent problems of that kind could in part explain the finding of Weismann (2009) that the FCPA did not have meaningful effects on the behaviors of US multinationals between 1977 and 2008.

Nevertheless, government policy should be based on more than firms' intentions. From a government policy standpoint, our finding that investors are no more dissuaded from investing by corruption than they are by legitimate costs of doing business suggests that anti-corruption interventions and campaigns based on moral suasion may be ineffective, at least in corrupt environments. Both anti-corruption authorities and corporate compliance officers must put policies and procedures into place that create meaningful threats of detection and punishment in line with the seminal studies of Abbink et al. (2002) and Olken (2007), both of which point to a strong deterrent effect of such policies. While our objective was to explore the possibility of a pure distaste-for-corruption effect, future work usefully could explore the interactions of deterrence with distaste because the presence of a strong anti-corruption policy may increase the subjective cost of facilitating corruption.

Our finding that providing information about the extent of corruption can increase investment, though perhaps only if it is objective in nature, also has implications for policy. Governments, NGOs and international organizations should consider the possibility that such simple signals can change descriptive norms surrounding corruption by giving actors the sense that it's "just how things always are done". The tradeoffs inherent in boosting investment while increasing willingness to engage in activities that feed corrupt officials require careful consideration.

Supplementary Information The online version contains supplementary material available at https://doi. org/10.1007/s11127-021-00913-x.

Acknowledgements We thank the Busara Centre for Behavioural Economics for implementing the experiment and gratefully acknowledge funding from the Marcus Wallenberg and Otto A. Malm foundations, 
and the African Development Bank. Conflict of Interest: The authors declare that they have no conflict of interest

Funding Open Access funding provided by the IReL Consortium.

Open Access This article is licensed under a Creative Commons Attribution 4.0 International License, which permits use, sharing, adaptation, distribution and reproduction in any medium or format, as long as you give appropriate credit to the original author(s) and the source, provide a link to the Creative Commons licence, and indicate if changes were made. The images or other third party material in this article are included in the article's Creative Commons licence, unless indicated otherwise in a credit line to the material. If material is not included in the article's Creative Commons licence and your intended use is not permitted by statutory regulation or exceeds the permitted use, you will need to obtain permission directly from the copyright holder. To view a copy of this licence, visit http://creativecommons.org/licenses/by/4.0/.

\section{References}

Abbink, K. (2006). Laboratory experiments on corruption. In S. Rose-Ackerman (Ed.), The handbook of corruption (pp. 414-440). Edward Elgar.

Abbink, K., \& Hennig Schmidt, H. (2006). Neutral versus loaded instructions in a bribery experiment. Experimental Economics, 9(2), 103-121.

Abbink, K., Irlenbusch, B., \& Renner, E. (2002). An experimental bribery game. Journal of Law, Economics, and Organization, 18(2), 428-454.

Alexander, A. C., Bågenholm, A., \& Charron, N. (2019). Are women more likely to throw the rascals out? The mobilizing effect of social service spending on female voters. Public Choice, 184, 235-261.

Apergis, N., Dincer, O. C., \& Payne, J. E. (2010). The relationship between corruption and income inequality in US states: Evidence from a panel cointegration and error correction model. Public Choice, 145(1-2), 125-135.

Armantier, O., \& Boly, A. (2012). On the external validity of laboratory experiments on corruption. In D. Serra and L. Wantchekon (Eds.), New Advances in Experimental Research on Corruption (Research in Experimental Economics, Volume 15), pp. 117-144. Bingley, UK: Emerald Group Publishing Limited.

Armantier, O., \& Boly, A. (2013). Comparing corruption in the laboratory and in the field in Burkina Faso and in Canada. The Economic Journal, 123(573), 1168-1187.

Azfar, O., \& Nelson, W. R. (2007). Transparency, wages, and the separation of powers: an experimental analysis of corruption. Public Choice, 130(3-4), 471-493.

Banerjee, R. (2016a). Corruption, norm violation and decay in social capital. Journal of Public Economics, $137,14-27$.

Banerjee, R. (2016b). On the interpretation of bribery in a laboratory corruption game: Moral frames and social norms. Experimental Economics, 19(1), 240-267.

Barr, A., \& Serra, D. (2009). The effects of externalities and framing on bribery in a petty corruption experiment. Experimental Economics, 12, 488-503.

Baucus, M. S. (1994). Pressure, opportunity and predisposition: A multivariate model of corporate illegality. Journal of Management, 20(4), 699-721.

Becker, G. S. (1968). Crime and punishment: an economic approach. In N. G. Fielding, A. Clarke, \& R. Witt (Eds.), The economic dimensions of crime (pp. 13-68). London: Palgrave Macmillan.

Beekman, G., Bulte, E. H., \& Nillesen, E. E. (2013). Corruption and economic activity: micro level evidence from rural Liberia. European Journal of Political Economy, 30, 70-79.

Beekman, G., Bulte, E., \& Nillesen, E. (2014). Corruption, investments and contributions to public goods: experimental evidence from rural Liberia. Journal of Public Economics, 115, 37-47.

Bénassy-Quéré, A., Coupet, M., \& Mayer, T. (2007). Institutional determinants of foreign direct investment. World Economy, 30(5), 764-782.

Berg, J., Dickhaut, J., \& McCabe, K. (1995). Trust, reciprocity, and social history. Games and Economic Behavior, 10(1), 122-142.

Bernheim, B. D., \& Kartik, N. (2014). Candidates, character, and corruption. American Economic Journal: Microeconomics, 6(2), 205-246.

Bicchieri, C., \& Xiao, E. (2009). Do the right thing: but only if others do so. Journal of Behavioral Decision Making, 22(2), 191-208. 
Blonigen, B. A., Davies, R. B., Waddell, G. R., \& Naughton, H. T. (2007). FDI in space: spatial autoregressive relationships in foreign direct investment. European Economic Review, 51(5), 1303-1325.

Boas, T. C., Hidalgo, F. D., \& Melo, M. A. (2019). Norms versus action: Why voters fail to sanction malfeasance in Brazil. American Journal of Political Science, 63(2), 385-400.

Boly, A., Gillanders, R., \& Miettinen, T. (2019). Deterrence, contagion, and legitimacy in anticorruption policy making: an experimental analysis. The Journal of Legal Studies, 48(2), 275-305.

Brandts, J., \& Schwieren, C. (2009). Frames and economic behavior: An experimental study. Universitat Autònoma de Barcelona.

Camerer, C. F. (2015). The promise and success of lab-field generalizability in experimental economics: A reply to Levitt and List. In G. Fréchette \& A. Schotter (Eds.), Handbook of experimental economic methodology (pp. 249-295). Oxford: Oxford University Press.

Chong, A., De La, A. L. O., Dean Karlan, Leonard Wantchekon. (2015). Does corruption information inspire the fight or quash the hope? a field experiment in Mexico on voter turnout, choice, and party identification. The Journal of Politics, 77(1), 55-71.

Cubitt, R. P., Drouvelis, M., \& Gächter, S. (2011). Framing and free riding: emotional responses and punishment in social dilemma games. Experimental Economics, 14, 254-272.

d'Adda, G., Darai, D., Pavanini, N., \& Weber, R. A. (2017). Do leaders affect ethical conduct? Journal of the European Economic Association, 15(6), 1177-1213.

Dawid, H., \& Feichtinger, G. (1996). On the persistence of corruption. Journal of Economics, 64(2), $177-193$.

Daude, C., \& Stein, E. (2007). The quality of institutions and foreign direct investment. Economics and Politics, 19(3), 317-344.

Dearmon, J., \& Grier, R. (2011). Trust and the accumulation of physical and human capital. European Journal of Political Economy, 27(3), 507-519.

Djankov, S., Ganser, T., McLiesh, C., Ramalho, R., \& Shleifer, A. (2010). The effect of corporate taxes on investment and entrepreneurship. American Economic Journal: Macroeconomics, 2(3), 31-64.

Dong, B., Dulleck, U., \& Torgler, B. (2009). Social norms and corruption. In Ciccone, A. (ed). Proceedings of the European Economic Association and the Econometric Society European Meeting pp. 1-48. Catalonia, Spain: Barcelona Graduate School of Economics .

Dong, B., Dulleck, U., \& Torgler, B. (2012). Conditional corruption. Journal of Economic Psychology, 33(3), 609-627.

Dreber, A., Ellingsen, T., Johannesson, M., \& Rand, D. (2013). Do people care about social context? framing effects in dictator games. Experimental Economics, 16(3), 349-371.

Dusek, L., Ortmann, A., \& Lizal, L. (2005). Understanding corruption and corruptibility through experiments: a primer. Prague Economic Papers, 14(2), 147-162.

Everhart, S. S., Vazquez, J. M., \& McNab, R. M. (2009). Corruption, governance, investment and growth in emerging markets. Applied Economics, 41(13), 1579-1594.

Fan, C. S., Lin, C., \& Treisman, D. (2009). Political decentralization and corruption: evidence from around the world. Journal of Public Economics, 93(1-2), 14-34.

Fisman, R., \& Miguel, E. (2007). Corruption, norms, and legal enforcement: evidence from diplomatic parking tickets. Journal of Political Economy, 115(6), 1020-1048.

Fisman, R., \& Svensson, J. (2007). Are corruption and taxation really harmful to growth? firm level evidence. Journal of Development Economics, 83(1), 63-75.

Foresta, A. (2020). The rise of populist parties in the aftermath of a massive corruption scandal. Public Choice, 184, 289-306.

Froot, K. A., \& Stein, J. C. (1991). Exchange rates and foreign direct investment: an imperfect capital markets approach. The Quarterly Journal of Economics, 106(4), 1191-1217.

Gatti, R., Paternostro, S., Rigolini, J. (2003). Individual attitudes toward corruption: Do social effects matter? World Bank Policy Research Working Paper No. 3122

Georgarakos, D., \& Pasini, G. (2011). Trust, sociability, and stock market participation. Review of Finance, 15(4), 693-725.

Gillanders, R., \& Neselevska, O. (2018). Public sector corruption and trust in the private sector. Journal of International Development, 30(8), 1288-1317.

Gillanders, R., \& Parviainen, S. (2018). Corruption and the shadow economy at the regional level. Review of Development Economics, 22(4), 1729-1743.

Guiso, L., Sapienza, P., \& Zingales, L. (2008). Trusting the stock market. The Journal of Finance, 63(6), 2557-2600.

Gupta, S., Davoodi, H., \& Alonso-Terme, R. (2002). Does corruption affect income inequality and poverty? Economics of Governance, 3(1), 23-45. 
Head, K., \& Mayer, T. (2004). Market potential and the location of Japanese investment in the European Union. Review of Economics and Statistics, 86(4), 959-972.

Johnson, N. D., LaFountain, C. L., \& Yamarik, S. (2011). Corruption is bad for growth (even in the United States). Public Choice, 147(3-4), 377-393.

Kessler, J. B., \& Leider, S. (2012). Norms and contracting. Management Science, 58(1), 62-77.

Kessler, J. B., \& . Vesterlund L. . (2015). The external validity of laboratory experiments: qualitative rather than quantitative effects. In G. Fréchette \& A. Schotter (Eds.), Handbook of experimental economic methodology (pp. 391-406). Oxford: Oxford University Press.

Köbis, N. C., Van Prooijen, J. W., Righetti, F., \& Van Lange, P. A. (2015). "Who doesn't?"-The impact of descriptive norms on corruption. PLOS ONE, 10(6), e0131830.

Lawless, M. (2013). Do complicated tax systems prevent foreign direct investment? Economica, 80(317), $1-22$.

Leliveld, M. C., van Dijk, E., \& van Beest, I. (2008). Ownership in bargaining: introducing the giving, splitting, and taking ultimatum bargaining game. Personality and Social Psychology Bulletin, 34, 1214-1225.

Keysar, B., Converse, B. A., Wang, J., \& Epley, N. (2008). Reciprocity is not give and take: asymmetric reciprocity to positive and negative acts. Psychological Science, 19, 1280-1286.

Mauro, P. (1995). Corruption and growth. The Quarterly Journal of Economics, 110(3), 681-712.

Morris, S. D., \& Klesner, J. L. (2010). Corruption and trust: Theoretical considerations and evidence from Mexico. Comparative Political Studies, 43(10), 1258-1285.

Nabin, M. H., \& Bose, G. (2008). Partners in crime: Collusive corruption and search. The BE Journal of Economic Analysis and Policy. https://doi.org/10.2202/1935-1682.1926

Olken, B. A. (2007). Monitoring corruption: evidence from a field experiment in Indonesia. Journal of Political Economy, 115(2), 200-249.

Olken, B. A. (2009). Corruption perceptions vs. corruption reality. Journal of Public Economics, 93(7-8), 950-964.

Razafindrakoto, M., \& Roubaud, F. (2010). Are international databases on corruption reliable? a comparison of expert opinion surveys and household surveys in sub-Saharan Africa. World Development, $38(8), 1057-1069$.

Rivas, M. F. (2013). An experiment on corruption and gender. Bulletin of Economic Research, 65(1), 10-42.

Roodman, D., Nielsen, M. Ø., MacKinnon, J. G., \& Webb, M. D. (2019). Fast and wild: Bootstrap inference in Stata using boottest. The Stata Journal, 19(1), 4-60.

Rose-Ackerman, S. (2002). "Grand" corruption and the ethics of global business. Journal of Banking \& Finance, 26(9), 1889-1918.

Schram, A. (2005). Artificiality: The tension between internal and external validity in economic experiments. Journal of Economic Methodology, 12(2), 225-237.

Seligson, M. A. (2002). The impact of corruption on regime legitimacy: a comparative study of four Latin American countries. The Journal of Politics, 64(2), 408-433.

Tirole, J. (1996). A theory of collective reputations (with applications to the persistence of corruption and to firm quality). The Review of Economic Studies, 63(1), 1-22.

Treisman, D. (2007). What have we learned about the causes of corruption from ten years of cross-national empirical research? Annual Review of Political Science, 10, 211-244.

Udomkerdmongkol, M., Morrissey, O., \& Görg, H. (2009). Exchange rates and outward foreign direct investment: US FDI in emerging economies. Review of Development Economics, 13(4), 754-764.

Uslaner, E. M. (2004). Trust and corruption. In J. Lambsdorf, M. Taube, \& M. Schramm (Eds.), The new institutional economics of corruption (pp. 90-106). Routledge.

Wei, S. J. (2000). How taxing is corruption on international investors? Review of Economics and Statistics, $82(1), 1-11$.

Weismann, M. F. (2009). The Foreign Corrupt Practices Act: The failure of the self-regulatory model of corporate governance in the global business environment. Journal of Business Ethics, 88(4), 615-661.

Zakharov, N. (2019). Does corruption hinder investment? Evidence from Russian regions. European Journal of Political Economy, 56, 39-61.

Publisher's Note Springer Nature remains neutral with regard to jurisdictional claims in published maps and institutional affiliations. 